See discussions, stats, and author profiles for this publication at: https://www.researchgate.net/publication/31492566

\title{
Phylogenetics of South American Biomphalaria and description of a new species (Gastropoda: Planorbidae)
}

Article in Journal of Molluscan Studies · August 2006

DOI: 10.1093/mollus/eyl003 · Source: OAI

CITATIONS

READS

13

172

6 authors, including:

Luz Elena Velásquez

University of Antioquia

Q Roberta Lima Caldeira

168 PUBLICATIONS 551 CITATIONS

Fundação Oswaldo Cruz

199 PUBLICATIONS 1,201 CITATIONS

SEE PROFILE

SEE PROFILE

Some of the authors of this publication are also working on these related projects:

Project Rutas hacia una ruralidad sostenible desde la equidad y la diversidad View project 


\title{
PHYLOGENETICS OF SOUTH AMERICAN BIOMPHALARIA AND DESGRIPTION OF A NEW SPEGIES (GASTROPODA: PLANORBIDAE)
}

\author{
VIGTORIA E. ESTRADA ${ }^{1,2}$, LUZ E. VELÁSQUEZ ${ }^{1}$, ROBERTA L. CALDEIRA ${ }^{3}$, \\ EDUAR E. BEJARANO ${ }^{4}$, WINSTON ROJAS ${ }^{5}$ AND OMAR S. CARVALHO ${ }^{3}$ \\ ${ }^{1}$ Programa de Estudio y Control de Enfermedades Tropicales-PECET, Universidad de Antioquia, Colombia; \\ ${ }^{2}$ Grupo de Sistemática Molecular, Universidad Nacional de Colombia Sede Medellín, Colombia; \\ ${ }^{3}$ Centro de Pesquisas René Rachou-FIOCRUZ, BH, MG, Brazil; \\ ${ }^{4}$ Grupo de Investigaciones Biomédicas, Universidad de Sucre, Colombia; \\ ${ }^{5}$ Genética Molecular, Universidad de Antioquia, Colombia
}

(Received 16 February 2004; accepted 20 October 2005)

\begin{abstract}
The planorbid snail Biomphalaria edisoni n. sp. is described from morphological and molecular characters, based on specimens collected at two localities in Colombia. The new species has the typical features of the genus, as well as the following characteristics: vaginal pouch, numerous prostatic diverticula arranged in racemes, penis sheath/prepuce ratio of approximately 2 and a penial complex half the length of the cephalic portion of the female duct. These elements differentiate it from B. kuhniana, which was also present in one of the localities, and also from B. prona, B. helophila and B. nicaraguana, with which it has greater morphological similarities. Phylogenetic analysis of the nucleotide sequences of the internal spacers of the ribosomal DNA transcript (ITS1, ITS2) of B. edisoni n. sp. and 14 neotropical Biomphalaria species indicates that the former belongs to the monophyletic group including $B$. prona and $B$. sp. from Cuba. The genetic distances within this monophyletic group are however great enough for $B$. edisoni n. sp. to be regarded as a separate species. Thus morphology, phylogenetic tree topology and genetic distances all support the recognition of $B$. edisoni as a new species.
\end{abstract}

\section{INTRODUGTION}

Twenty species of planorbid snails of the genus Biomphalaria have been described from the Americas. These have been intensively studied as some species are implicated in the transmission of Schistosoma mansoni Sambon, 1907, the trematode responsible for schistosomiasis (Malek, 1985; Paraense, 1988). This is a serious public health problem that affects several million people in the neotropics and generates considerable economic losses (World Health Organization, 1993, 1998).

Studies on Biomphalaria have emphasized the identification of species susceptible to $S$. mansoni as an important prerequisite of control strategies. Taxonomic studies of these snails have traditionally focussed on the morphology of the reproductive system (Paraense, 1975). However, determination of some species is complicated by the similarity shown by these characters (Paraense, 1988). Molecular techniques have been used to try to overcome this problem (Caldeira et al., 1998; Spatz et al., 1999).

Although there are no records of autochthonous cases of schistosomiasis in Colombia, Velásquez et al. (2002) reported five species of snails of the genus Biomphalaria from the country: B. kuhniana (Clessin, 1883), B. oligoza Paraense, 1974, B. peregrina D'Orbigny, 1835, B. straminea (Dunker, 1848) and B. amazonica Paraense, 1966. Biomphalaria straminea is an intermediate host for $S$. mansoni, and the species is mainly responsible for $S$. mansoni transmission in NE Brazil (Paraense \& Correa, 1989). Neither $B$. peregrina nor B. amazonica has ever been found to be naturally infected, although both have been infected experimentally with strains of S. mansoni (Corrêa \& Paraense, 1971; Paraense \& Corrêa, 1973). Most Colombian records of Biomphalaria have been based on morphological characters and it is important to develop new taxonomic tools that permit corroboration of

Correspondence: Victoria E. Estrada; e-mail: vestrada@epm.net.co these species identifications. This is increasingly important in epidemiological terms because of the current expansion in the geographical distribution of $S$. mansoni and the presence of risk areas for the establishment of this parasite in Colombia.

This study provides data on morphological and molecular characters to confirm the presence of a new Biomphalaria species in Colombia.

\section{MATERIAL AND METHODS}

\section{Collection sites}

Material was collected from two sites. The Cali population was collected in February 2000 in the artificial lakes of the University of Valle del Cauca in Cali $\left(3^{\circ} 22^{\prime} \mathrm{N}, 76^{\circ} 31^{\prime} \mathrm{W}\right)$, water temperature was $28^{\circ} \mathrm{C}$ and $\mathrm{pH}$ 8.4. The Puente Iglesias population was collected on the west side of the El Sapo stream, $2 \mathrm{~km}$ upstream of the mouth of the Cauca river, in June-July 2001 at the Inspección Puente Iglesias, in the municipality of Fredonia $\left(5^{\circ} 48^{\prime} \mathrm{N}, 75^{\circ} 40^{\prime} \mathrm{W}\right)$; they were found in fine sediments at depths of less than $5 \mathrm{~cm}$ in slow-flowing water with a temperature of $31-35^{\circ} \mathrm{C}$ and $\mathrm{pH} 8.4$.

\section{Morphological study}

Snails were transported live to the Medical Malacology Laboratory (MML) of PECET, where they were maintained in aquaria with artificially aerated dechlorinated water and a sterile mud substrate. They were fed on fresh lettuce. After 2 days of acclimatization, all the specimens were placed individually in vials containing dechlorinated water. These were exposed to a light source for $8 \mathrm{~h}$ as a stimulus to provoke the emission of cercariae. The snails that voided cercariae were then counted and installed in a specially conditioned aquarium. This assay was 
repeated every 15 days on three consecutive occasions to give time for the youngest larvae to reach the cercaria stage.

Thirty active adult specimens of each population were selected for the taxonomic study. The snails were relaxed in $0.05 \%$ Nembutal for $8 \mathrm{~h}$ and killed in water at $70^{\circ} \mathrm{C}$. The soft parts were separated from the shell, fixed in Railliet-Henry's solution $(930 \mathrm{ml}$ distilled water, $6.0 \mathrm{~g} \mathrm{NaCl}, 50 \mathrm{ml} 40 \%$ formalin and $20 \mathrm{ml}$ acetic acid) and dissected following the methodology proposed by Deslandes (1951) and Paraense (1966, 1975, 1976, 1988). Measurements of the reproductive system were made with an eyepiece micrometer $( \pm 0.01 \mu \mathrm{m})$. The shells were measured with a digital calibrator $( \pm 0.01 \mathrm{~mm})$ and stored in flasks protected with cotton wool.

Voucher specimens of the material were deposited in the malacological collections of the PECET-MML (PECET MOL 173-187) and the Centro de Pesquisas René Rachou-Fiocruz (5564-5593).

\section{Molecular study}

Internal spacers of the transcript of ribosomal DNA (ITS rDNA) were selected for the molecular study, including the 5.8S gene with the ITS1 and ITS2 flanking regions, which have proved useful in taxonomic studies of the genus Biomphalaria (Campbell et al., 2000; Vidigal et al., 2000a; Dejong et al., 2001). Genomic DNA was extracted from two specimens from each study population. Extracts were made from the foot of each individual by the phenol-chloroform method (Vidigal et al., 1994). The ITS1 region was amplified with the primers ETTS2 (5-TAACAAGGTTTCGGTAGGTGAA-3) (Kane \& Rollinson, 1994) and ITS1R (5-ACGAGCGAGTGATCG ACCGC-3) (Vidigal et al., 2004), whereas the ITS2 segment was amplified with the primers ETTS1 (5'-TGCTTAAGTTC AGCGGGT-3') (Kane \& Rollinson, 1994) and ITS2F (5-CGTCGGTCTGAGGGTCGGTTTGC-3) (Vidigal et al., 2000b). The polymerase chain reaction (PCR) mixture had a final volume of $20 \mu \mathrm{l}$ and was made according to the conditions described by Vidigal et al. (2000b). PCR products were sequenced in the forward and reverse directions on an ABI 3700 Capillary DNA sequencer, using Big Dye fluorescent terminators (Big Dye cycle sequencing kit version 2; Perkin Elmer). The sequences obtained were edited with the SeqMan programme 3.03 (DNAStar, Inc.) and aligned with homologous sequences of 14 New World species of Biomphalaria (DeJong et al., 2001), using the CLUSTAL W 1.7 programme (Thompson, Higgins, \& Gibson, 1994). The resulting alignment was refined by eye.

For the phylogenetic analysis, the ITS1 and ITS2 sequences were united in a single data set, resulting in a matrix of 1256 characters. This included B. kuhniana, B. straminea, B. amazonica, $B$. sp. from Bolivia, B. intermedia, B. edisoni n. sp., B. prona, B. sp. Hbl from Cuba, B. occidentalis, B. tenagophila, B. sp. Zf from Cuba, B. temascalensis, B. sp. from Puerto Rico, B. obstructa and B. helophila (GenBank accession numbers AY030378-AY030391 and AY030393-AY030399). Sequences of B. glabrata were originally included as an outgroup, but later removed, because the results obtained (data not shown) presented contradictions with those exposed by DeJong et al. (2001). It was also decided that $B$. glabrata could provoke long-branch attraction, because of the high divergence that it showed with the group of neotropical Biomphalaria species.

Maximum parsimony analysis was performed using the phylogenetic analysis using parsimony $4.0 \mathrm{~b} 10$ programme for Macintosh (Swofford, 2002). As a result, a heuristic search was performed using 10 random replicate addition searches with tree-bisection-reconnection branch swapping to adequately sample the large tree space. In the analysis, all characters were unordered and unweighted, gaps introduced in the alignment process were treated as missing data and topological constraints were not enforced. Bootstrap support (Felsenstein, 1985) was estimated by a heuristic search on 1000 bootstrap pseudoreplicates (each with 10 random additions) and tree bisectionreconnection (TBR) branch swapping. In order to root the resultant tree and determine character polarity, Biomphalaria helophila (GenBank accession number AY030399) was included as an outgroup. The derived trees were visualized by Treeview 1.6.6 (Page, 1996). The ITS1 and ITS2 gene sequences obtained from this study were deposited in GenBank under the accession numbers AY364446-AY364452.

Measures of nucleotide diversity were calculated for each clade using DnaSP 3.5 (Rozas \& Rozas, 1999).

\section{RESULTS}

Two species of Biomphalaria were identified in the samples collected from Puente Iglesias: B. kuhniana and Biomphalaria n. sp. described in the present article. In the latter, $4 / 43(9.3 \%)$ of the specimens were parasitized with a cercaria of the genus Echinostome (Fig. 1). These cercariae show marked morphological differences to the brevifurcate-apharyngeate ones produced by trematodes of the family Schistosomaidae. No specimens of $B$. kuhniana were found parasitized with trematodes.

\section{SYSTEMATIC DESCRIPTION}

\section{Family PLANORBIDAE H. \& A. Adams, 1855} Genus Biomphalaria Preston, 1910

Type species: Biomphalaria smithii Preston, 1910.

Diagnosis: Adult shell is nearly always discoidal; blood is red and jaw is T-shaped, with dorsal part composed of single crescentshaped piece. Central tooth of radula has only two cusps, with no small accessory denticles on their shoulders. There is neither a preputial organ in preputium nor set of flagellar glands attached externally at upper tip of penis sac. Opening of penis is terminal and tip of penis has no stylet (Paraense, 1972).

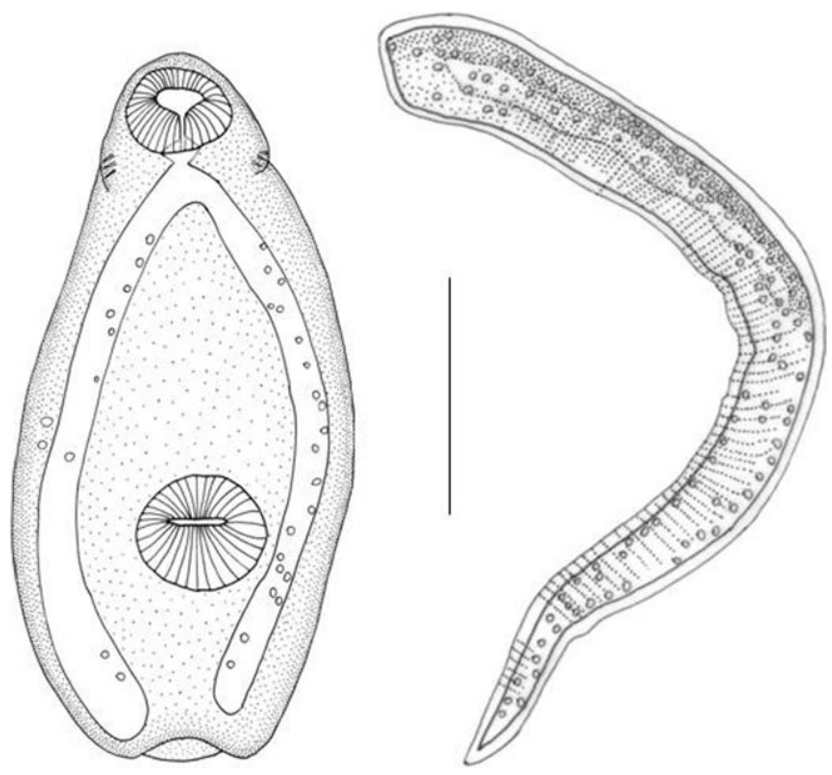

Figure 1. Echinostome cercaria parasitizing Biomphalaria edisoni n. sp. from Puente Iglesias. Scale bar $=0.1 \mathrm{~mm}$. 
A

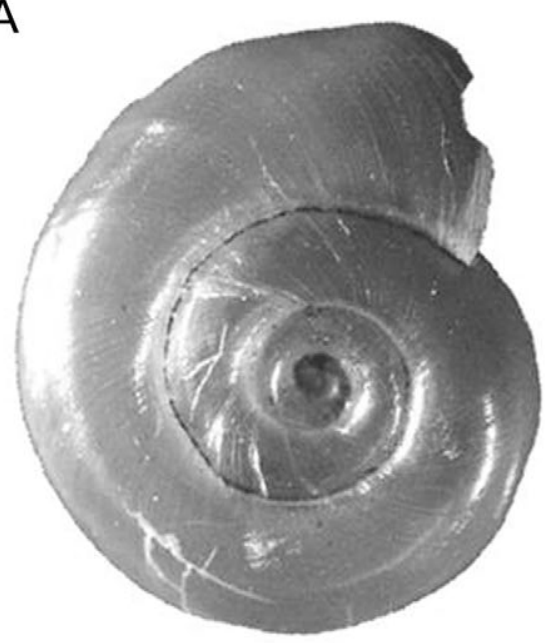

B

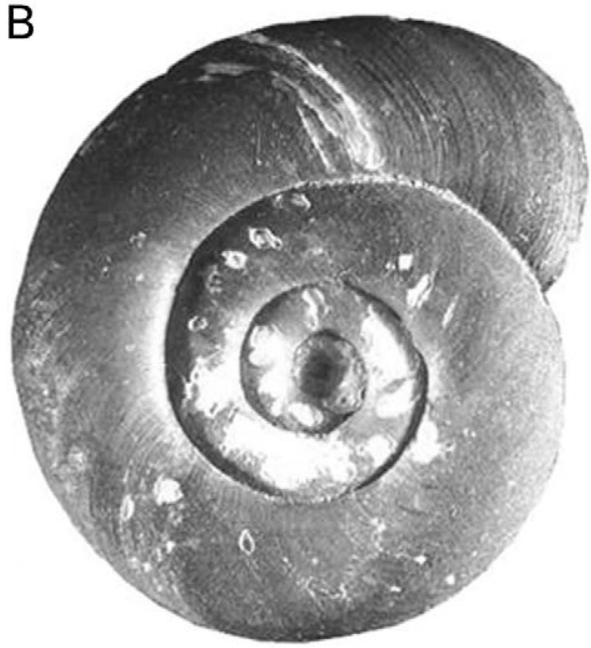

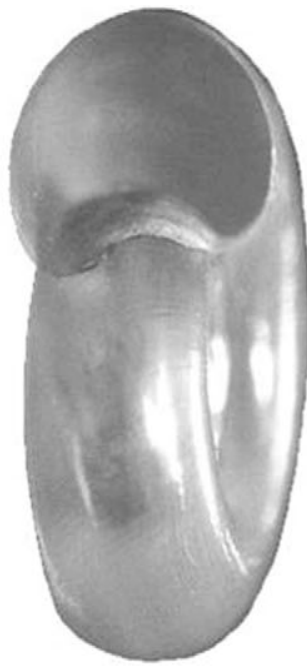
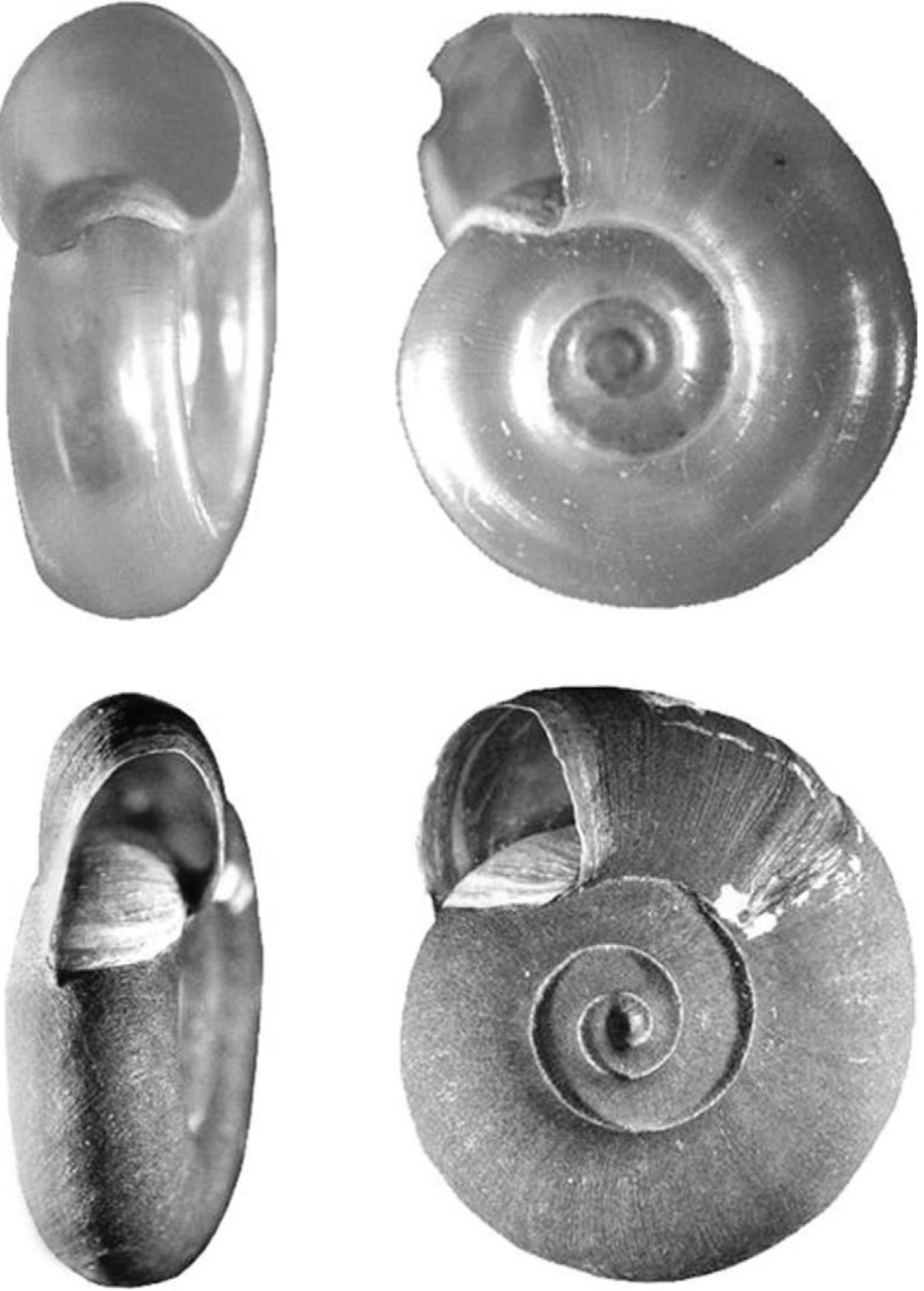

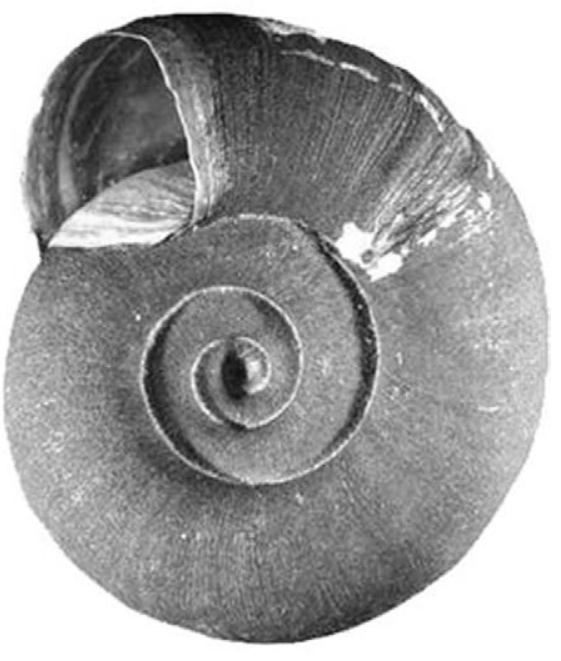

Figure 2. Shells of Biomphalaria edisoni n. sp. from the original localities. A. Cali. B. Puente Iglesias. Scale bar $=5 \mathrm{~mm}$.

\section{Biomphalaria edisoni new species}

(Figures 2-3)

Type material: Holotype: Artificial lakes of the University of Valle del Cauca in Cali, Colombia $\left(3^{\circ} 22^{\prime} \mathrm{N}, 76^{\circ} 31^{\prime} \mathrm{W}\right)$, deposited in the malacological collection at the PECET, Colombia (Reference PECET MOL 178), which is registered at the Instituto Von Humbolt, VHET 37. Five paratypes were deposited at the Centro de Pesquisas René Rachou-Fiocruz (5564-5568).

Shell: Largest shell $11 \mathrm{~mm}$ diameter and $3.3 \mathrm{~mm}$ high, with 5.25 whorls, increasing slowly in diameter. Sutures deep, whorls rounded on both sides, forming a more pronounced siphon on left side than on right. Periphery of shell rounded. Opening oval, inclined towards left; right labium presenting more growth than left, thus increasing depth of funnel. Surface of internal labium covered by thin white membrane. Periostracum of wild snails dark brown, but translucid and very thin in laboratory specimens (Fig. 2).

Reproductive anatomy: Reproductive system of ovotestis composed of 30-50 rounded diverticula, most of them branched, which diminish in size towards distal extremity in protoconch. This continues as hermaphrodite canal, or ovispermiduct, having seminal vesicles with conspicuous parietal diverticula in its proximal third (Fig. 3). Ovispermiduct terminates in junction, which divides to give rise to male and female ducts. The latter begins with a somewhat cylindrical oviduct that terminates in a marked dilatation, the oviduct pouch. This is followed by nidamental gland, wider than oviduct and flattened laterally, which narrows towards anterior region; this leads to uterus and subsequently vagina. To right of this organ is spermatheca, an oval sac-like structure opening into vagina by means of a narrow canal that measures approximately half length of this sac. Vagina with pouch located between female pore and insertion of spermathecal duct. Length of pouch corresponds approximately to that of spermathecal duct and width almost half circumference of vagina. Caudal portion of female duct about $60 \%$ of length of cephalic portion; ratio between their lengths varying from 0.55 to 0.71 in Cali population; $0.46-0.70$ in Puente Iglesias population. Ratio between lengths of cephalic portion and penial complex varies from 1.87 to 2.50 in Cali population, and from 1.28 to 2.57 in that from Puente Iglesias.

Male conduit consists of spermiduct, prostate, vas deferens and penial complex. Spermiduct describes a sinuous trajectory, which at level of oviduct pouch continues in prostate, consisting 
A

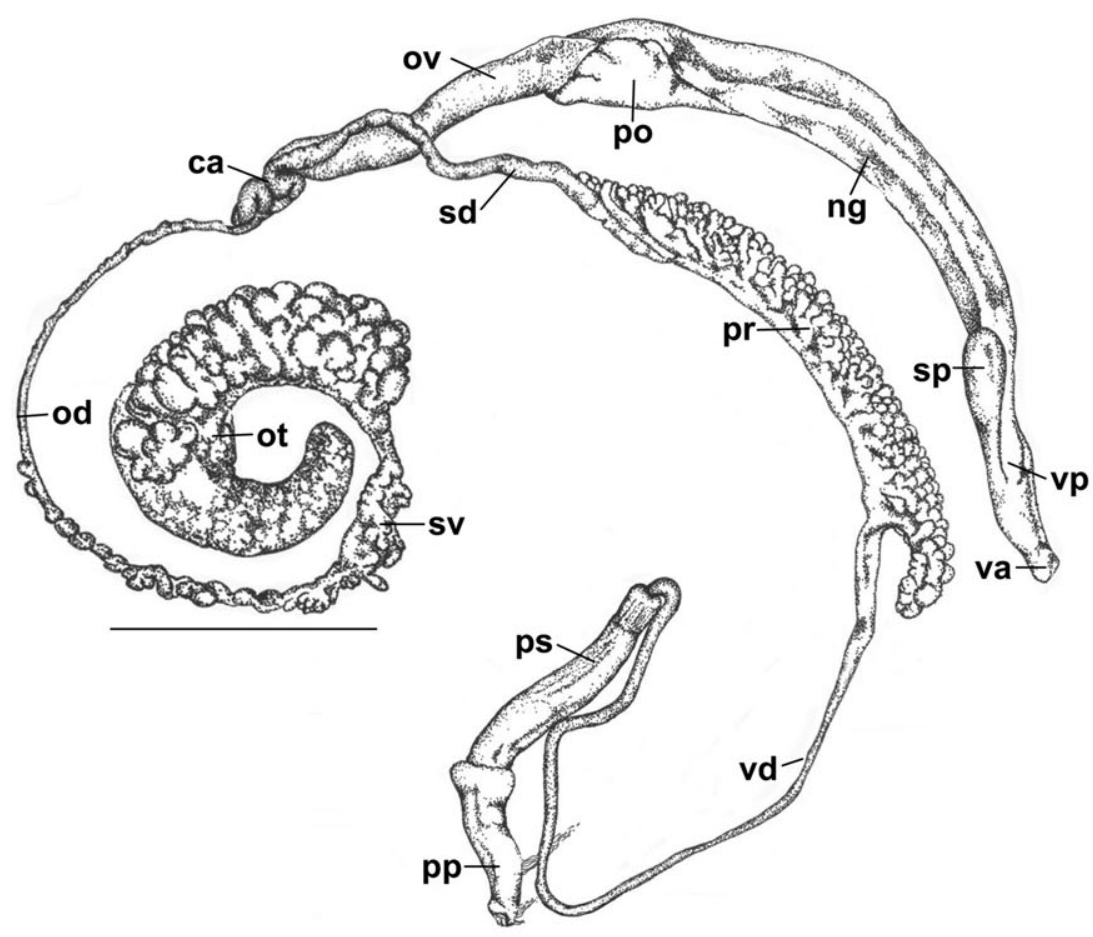

$\mathrm{B}$

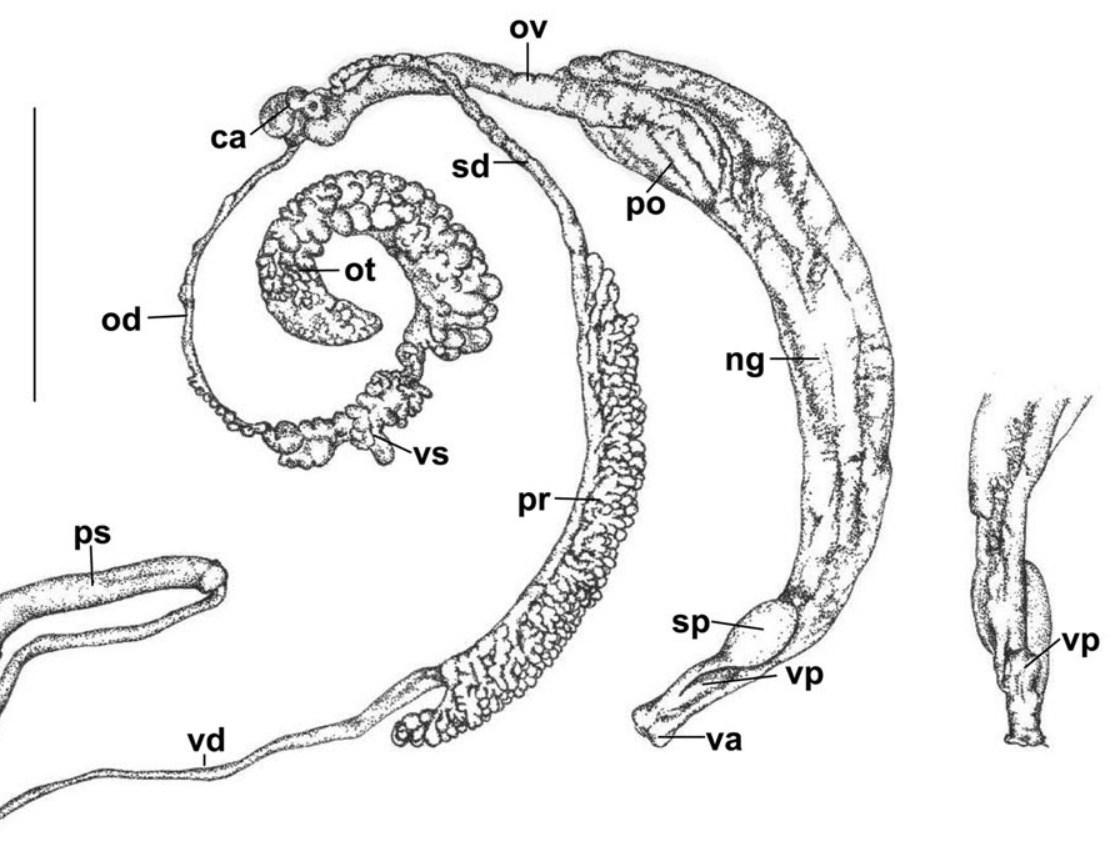

Figure 3. Biomphalaria edisoni n. sp. reproductive system. A. Cali. B. Puente Iglesias. Abbreviations: ag, albumen gland; ca, carrefour; ng, nidamental gland; od, ovispermiduct; ot, ovotestis; ov, oviduct; po, oviduct pouch; pp, preputium; pr, prostate; ps, penis sheath; sd, spermiduct; sp, spermatheca; $\mathrm{sv}$, seminal vesicle; va, vagina; vd, vas deferens; vp, vaginal pouch. Scale bar $=1 \mathrm{~mm}$.

of prostatic canal from which emerges a row of numerous diverticula with nodular ramifications. Beyond diverticula, prostatic canal narrows and continues as vas deferens, descending to cephalic extremity of prepuce and then ascending in a thicker segment than previously to pouch of penis, where it is about half width of penis sheath. Penial complex or copulatory apparatus comprises penis, penis sheath and prepuce. Penis sheath almost twice as long as prepuce, ratio of lengths of these organs (pp) 1.56-2.21 (mean $1.80 \pm$ SD 0.21) for Puente Iglesias population, $1.25-2.18$ (mean $1.68 \pm \mathrm{SD} 0.25$ ) for Cali population. It was notable that the prostatic diverticula did not cover the spermatheca and that the penial complex is about one-third of the length of the female duct from the carrefour to the external pore. Penial complex about half length of cephalic portion of female duct; ratio 1:2.10 for Cali population and 1:1.76 for Puente Iglesias population. 
Etymology: The species is dedicated to the memory of Edison Correa, a promising young entomologist from Medellín, for his enormous and valuable contribution to PECET-MML. He regularly collected freshwater snails for the group in the course of his fieldwork and helped compile inventories of molluscan species. Edison was tragically killed in Vereda La Hormiga, Putumayo, SW Colombia on 13 September 1998 while on a field collecting trip.

Remarks: Anatomical differences from closely related species are considered in the Discussion.

\section{PHYLOGENETIC ANALYSIS}

One specimen of B. edisoni n. sp. (GenBank accession number AY364449) was excluded from the phylogenetic analysis, because it limited the number of characters for comparison.

After excluding the gaps, the ITS1 and ITS2 combined sequences for B. edisoni n. sp. resulted in 953 sites, of which nine are polymorphic, with mean base frequencies as follows: $\mathrm{A}=0.2047, \mathrm{C}=0.2739, \mathrm{G}=0.2766$ and $\mathrm{T}=0.2448$, the three sequences analysed corresponding to different haplotypes. For all species, this resulted in 827 characters, of which 215 are polymorphic; 13 of these polymorphisms possess one state in $B$. edisoni and another in the remaining species. Excluding the outgroup, the transition/transversion rates were $1.3 / 1$. The parsimony analyses of the combined data produced 27 trees, each consisting of 349 steps, with a consistency index of 0.77 and a retention index of 0.83 . The consensus tree is show in Figure 4.

Two main clades were formed. The first is species-rich and includes neotropical taxa, and has four subclades: the first of these contains $B$. straminea and B. kuhniana, the second B. amazonica and $B$. sp. of Bolivia, the third B. prona, B. edisoni n. sp. and $B$. sp. Hbl from Cuba, and the last one, B. tenagophila and B. occidentalis. Biomphalaria intermedia could not be resolved.

The second main clade includes B. obstructa, B. sp. Zf from Cuba, $B$. sp. from Puerto Rico and B. temascalensis. These groups persist when the relationships are reconstructed by maximum likelihood and neighbour-joining methods (data not shown). Results from the separate analyses of data for ITS1 and ITS2 were not in conflict and, for simplicity, are not presented here.

The uncorrected $p$ distances within groups are shown in Table 1. The genetic distance within the $B$. straminea clade (B. kuhniana and B. straminea) was $2.5 \%$. When $B$. intermedia was included within this clade, the distance was $2.3 \%$. The distance within the group including $B$. edisoni is higher than that within any other clade, including the B. obstructa group.

Nucleotide diversity $(\boldsymbol{\pi})$ was determined within each clade. This makes pairwise comparisons within all the sequences, and thus constitutes an adequate measure of diversity. Within the $B$. temascalensis group, $\pi$ was 0.01903 and the average number of nucleotide differences $k=18.5$. For the group formed by B. tenagophila and B. occidentals, $\pi$ was $0.03282(k=32.0)$; for B. prona and B. edisoni n. sp. $0.0473(k=42.1)$; for the B. amazonica group $0.2523(k=23.1)$ and for $B$. kuhniana and B. straminea $0.01475(k=14)$. When $B$. intermedia was included in this last group, $\pi$ was $0.02155(k=20.1)$, but on placing it within the $B$. amazonica group, nucleotide diversity rose to 0.3233 $(k=30.0)$. This signifies that when diversity is compared with DNA characters, $B$. intermedia confers the same values on both groups. Within B. edisoni n. sp., the values were $\pi=0.00630$ and $k=6$, similar to the diversity found in $B$. prona $(\boldsymbol{\pi}=0.00731$ and $k=7)$.

\section{DISGUSSION}

Although we have no information on the status of Biomphalaria edisoni n. sp. as an intermediate host of $S$. mansoni, we found this species to be parasitized by a trematode of the family Echinostomatidae. Thus, it is important to undertake further studies.

Biomphalaria edisoni $\mathrm{n}$. sp. not only exhibits the typical characteristics of the genus (Paraense, 1975), but also presents distinct morphological traits that do not differ between individuals from the two known localities. In comparing the reproductive system of $B$. edisoni n. sp. with specimens of $B$. kuhniana from the same locality, marked differences were observed in the prostate, with the reproductive system of $B$. edisoni being characterized by having numerous diverticula arranged in racemes, whereas that of B. kuhniana has a few very simple diverticula. Additionally, B. kuhniana has vaginal corrugations and lacks the vaginal pouch, whereas $B$. edisoni n. sp. has no such corrugations but does possesses a vaginal pouch. The two species also differ in the ratio of the penis sheath to the prepuce (ps:pp), being 1.15:1 in B kuhniana and 1.8:1 in B. edisoni n. sp.

With regard to the other described species, we found B. edisoni n. sp. to show some similarities to the $B$. prona morph from the area around Lago Valencia in Venezuela. The prostate of both species possesses racemose diverticula; both have a vaginal pouch, and the length of the penial complex is one-third the length of the female duct. However, we encountered marked differences between the two species in the ps:pp ratio, which is about 1:1 in B. prona (Paraense et al., 1992), but almost 2:1 in B. edisoni. The maximum values of this ratio for $B$. prona do not overlap with the minimum ones recorded for $B$. edisoni n. sp. Another notable difference is that in B. edisoni, the segment of the vas deferens that ascends from the caudal extremity of the prepuce to the insertion in the penis sheath has a diameter double that of the preceding segment, unlike B. prona.

The general configuration of the reproductive system of the new species also shows similarities with $B$. helophila. However, in the latter the number of prostatic diverticula is small $(5-14)$, and most of them are bifurcated or trifurcated (Paraense, 1996), whereas in B. edisoni n. sp., there are numerous racemose diverticula. In addition, the ratio between the penial complex and the female duct, from the junction to the vagina, is 1:8 in B. helophila, but only 1:3 in B. edisoni n. sp.; B. helophila also lacks a vaginal pouch. Biomphalaria edisoni n. sp. resembles B. nicaraguana (Paraense, 2003), but differs from it in the following anatomical characters: presence of vaginal pouch; vas deferens notably narrower; ratio between caudal/cephalic portions of the female duct; ratio between cephalic portion of female duct/penial complex.

There are marked morphological differences between $B$. edisoni n. sp. and other Biomphalaria species known to be intermediate hosts of $S$. mansoni in the Americas. For example, B. glabrata is distinguished by the presence of a pigmented renal ridge, as well as its size and the ps:pp ratio, which in B. glabrata is about $0.5-1.5$ (Paraense, 1975). This last characteristic is also seen in $B$. tenagophila where the ps:pp ratio is 0.7-1.3 (Paraense, Ibañez \& Miranda, 1964). On the contrary, $B$. straminea has vaginal corrugations and lacks a vaginal pouch (Paraense, 1975), whereas B. edisoni n. sp. has no such corrugations but does possess a pouch.

There are also anatomical differences between B. edisoni n. sp. and Biomphalaria spp. known to be susceptible to $S$. mansoni in the laboratory. For example, although $B$. amazonica differs in the ps:pp ratio $(0.33-0.67)$ and in number of prostatic diverticula (8-12) (Paraense, 1966), B. havanensis and B. peregrina also differ in the ps:pp ratio, which is close to 1 (Malek, 1985).

Finally, B. edisoni n. sp. shows several notable morphological differences with $B$. andecola and $B$. equatoria. These species occur in the Andean region, but there is no information on their status as intermediate hosts of $S$. mansoni. The new species differs from $B$. andecola with respect to the ps:pp ratio, which is close to 1 (Malek, 1985). It differs from $B$. equatoria in the number of prostatic diverticula (10) and the ratio between the 


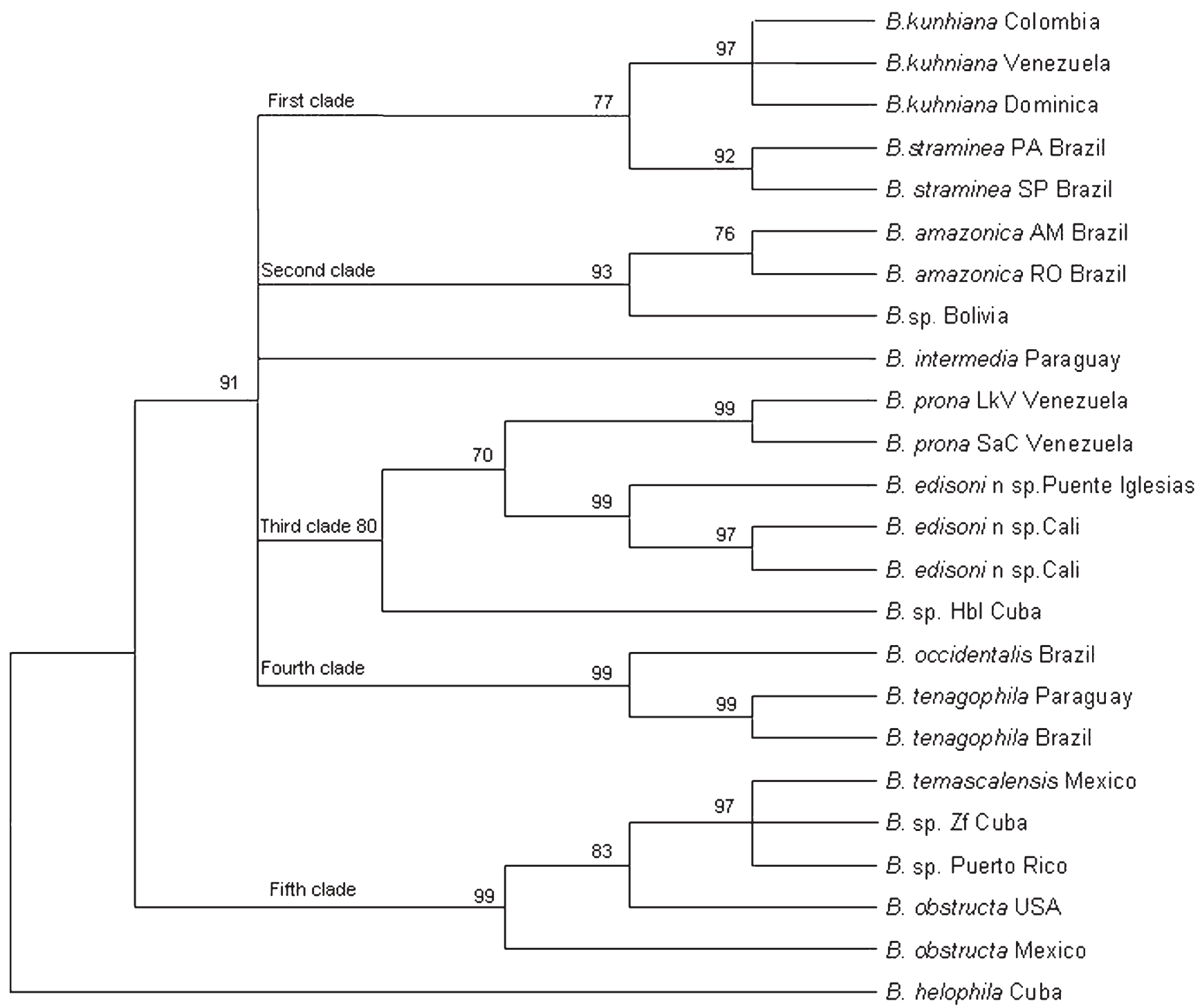

Figure 4. Strict consensus of 27 minimum-length trees constructed from the combined data set (ITS1 and ITS2) for Biomphalaria edisoni n. sp. (AY364446, AY364448-AY364452) and 14 New-World species of Biomphalaria (DeJong et al., 2001, sp. AY030378-AY030391 and AY030393AY030398). Trees were rooted with the sequences of Biomphalaria helophila (AY030399). Maximum parsimony bootstrap values $>50 \%$ are positioned next to each node. First to fifth monophyletic groups are as defined in Results.

Table 1. Average uncorrected $p$ distances (\%) within and between the species most closely related to $B$. edisoni $\mathrm{n}$. sp., based on the combined sequences of ITS1 and ITS2.

\begin{tabular}{lllllll}
\hline Clade & 1 & 2 & 3 & 4 & 5 & 6 \\
\hline 1 & $1.5(2.5)$ & & & & & \\
2 & 4.0 & $2.6(1.7-3.2)$ & & & & \\
3 & 7.3 & 8.0 & $5.8(0.4-9.2)$ & & & \\
4 & 7.4 & 7.5 & 9.9 & $3.3(4.9)$ & & \\
5 & 9.3 & 10.5 & 11.7 & 10.7 & $2.2(0.3-3.5)$ & \\
6 & 3.9 & 4.2 & 6.9 & 6.9 & 9.5 & ND \\
\hline
\end{tabular}

The ranges of the distances within the group are given in parentheses.

1, B. straminea clade; 2, B. amazonica clade; 3 , B. prona + B. edisoni clade; 4, B. tenagophila clade; 5 , B. obstructa clade; 6 , B. intermedia.

Abbreviation: ND, not determined. length of the cephalic portion of the female duct/penial complex (Paraense, 2004).

DeJong et al. (2001) demonstrated that ITS1 and ITS2 nucleotide sequences of single and combined set data for species used in this study (26 and 30 groups of DeJong) have bootstrap support $>70 \%$. This is why we decided to use combined data for this analysis. With respect to molecular characters, both the uncorrected $p$ distances and the inferred phylogenetic relationship of the genes, ITS1 and ITS2, constitute strong evidence that $B$. edisoni is a new species.

Based on the genetic distance values between the specimens of B. edisoni n. sp. $(0.4-0.9)$, the Puente Iglesias and Cali populations appear to represent a single species. In the maximum parsimony tree, these populations appear in the same clade supported by a bootstrap value of $99 \%$, and can thus be included in the monophyletic group consisting of $B$. prona and $B$. sp. from 
Cuba, which lies within the species-rich neotropical clade proposed by DeJong et al. (2001).

In our tree, the placement of $B$. intermedia outside the B. straminea complex is noteworthy, as it conflicts with the grouping proposed by DeJong et al. (2001). This may be due to the fact that our analysis differs in the exclusion of species that showed great divergence with respect to the species-rich neotropical clade - in the inclusion of B. edisoni n. sp.- and also to the fact that they used mitochondrial rDNA.

It should be noted that the genetic distance in $B$. intermedia does not increase when it is included within the $B$. straminea clade, a criterion consistent with the tree of DeJong et al. (2001), although nucleotide diversity does increase equally whether it is placed in this clade or that of B. amazonica. It should also be emphasized that despite the morphological similarities observed between $B$. edisoni $\mathrm{n}$. sp. and B. prona, the genetic distances (6.5-8.3) suggest that they represent different taxa when compared with the interspecific distances of 1.9-6.9 reported by DeJong et al. (2001). Furthermore, despite showing great phenotypic plasticity, $B$. prona was similar in its molecules when populations from Lago Valencia and elsewhere were compared (Paraense et al., 1992; Caldeira et al., 2000). Within this group, the distances between B. edisoni n. sp. and $B$. sp. HbL from Cuba were also greater than those between $B$. prona and $B$. sp. HbL from the same locality.

Despite the sympatry of $B$. edisoni n. sp. and $B$. kuhniana in the type locality of Puente Iglesias, both the genetic distances (6.5-7.7) and the topology of the phylogenetic tree support the conclusion that they represent distinct species of Biomphalaria. Although $B$. edisoni n. sp. appears within the third monophyletic group, B. kuhniana forms part of the first one. Additionally, the genetic distances between $B$. edisoni n. sp. and $B$. prona, or B. edisoni n. sp. and B. kuhniana, greatly exceed those observed within the first, second, fourth and fifth monophyletic groups.

Estimates of nucleotide diversity differ among clades and may reflect differences in demographic processes. For example, the greater nucleotide diversity of the clade that includes $B$. edisoni n. sp. could reflect greater divergence times within the group. However, given that this measure of diversity is very sensitive to sample size, such a conclusion should be made with caution.

In view of their morphological similarities and close phylogenetic relationships, it may be that $B$. edisoni n. sp., $B$. prona and $B$. sp. Hbl from Cuba constitute an interesting monophyletic group within the genus Biomphalaria, occurring in Cuba and the tropical Andean region of South America. Future studies should concentrate on resolving the taxonomic status of members of this group, and given the usefulness shown by the ITS1 and ITS2 markers in the present study, should take these molecular characters into account.

\section{ACKNOWLEDGEMENTS}

The authors thank Dr W Lobato Paraense, Department of Malacology, Instituto Oswaldo Cruz, world specialist in Biomphalaria, for confirming the presence of a new species among Colombian populations of Biomphalaria; Dr Helen Roberts, Laboratory of Human and Population Genetics, Department of Biology, University College, for her help in obtaining the sequences; Dr Iván Darío Vélez, Director of PECET, for his constant support of malacology research; María Carmenza Hincapié for the drawings; Imelda Vélez and Humberto Carvajal for their collaboration in snail collecting in Cali; and Juan Sebastián Escobar, Ana Correa and Juan Carlos Bedoya for their help in collecting from Puente Iglesias. This study was financed by grant CPT 0107 from the Comité para el Desarrollo de la Investigación of the University of Antioquia.

\section{REFERENCES}

GALDEIRA, R.L., VIDIGAL, T.H.D.A., PAULINELLI, S.T., SIMPSON, A.J.G. \& CARVALHO, O.S. 1998. Molecular identification of similar species of the genus Biomphalaria (Mollusca: Planorbidae) determined by a PCR-RFLP. Memórias do Instituto Oswaldo Cruz, 93: 219-225.

CALDEIRA, R.L., VIDIGAL, T.H.D.A., MATINELA, L., SIMPSON, A.J.G. \& CARVALHO, O.S. 2000. Identification of planorbids from Venezuela by polymerase chain reaction amplification and restriction fragment length polymorphism of ITS of the RNA ribosomal gene. Memórias do Instituto Oswaldo Cruz, 95: 171-177.

CAMPBELl, G., JONES, C.S., LOCKER, A.E., HUGHES, S., BROWN, D., NOBLE, L.R. \& ROLLINSON, D. 2000. Molecular evidence supports an African affinity of the neotropical freshwater gastropod, Biomphalaria glabrata Say 1818, an intermediate host for Schistosoma mansoni. Proceedings of the Royal Society of London, Series B, 267: 2351-2358.

CORREA, L.R. \& PARAENSE, W.L. 1971. Susceptibility of Biomphalaria amazonica to infection with two strains of Schistosoma mansoni. Revista do Instituto de Medicina Tropical de São Paulo, 13: 387-390.

DEJONG, R.J. et al. 2001. Evolutionary relationships and biogeography of Biomphalaria (Gastropoda: Planorbidae) with implications regarding its role as host of the human blood fluke, Schistosoma mansoni. Molecular Biology and Evolution, 18: 2225-2239.

DESLANDES, N. 1951. Técnica de dissecação e exame de planorbídeos. Revista do Serviço Especial de Saúde Pública, 4: 371-382.

FELSENSTEIN, J. 1985. Confidence limits on phylogenies: an approach using the bootstrap. Evolution, 39: 783-791.

KANE, R.A. \& ROLLINSON, D. 1994. Repetitive sequences in the ribosomal DNA internal transcribed spacer of Schistosoma haematobium, Schistosoma intercalatum and Schistosoma mattheii. Molecular and Biochemical Parasitology, 63: 153-156.

MALEK, E.A. 1985. Snail hosts of schistosomiasis and other snail-transmitted diseases in tropical America: A manual. WHO, Washington, USA.

PAGE, R.D.M. 1996. TREEVIEW: An application to display phylogenetic trees on personal computers. Computer Applications in the Biosciences, 12: 357-358.

PARAENSE, W.L. 1966. Biomphalaria amazonica and B. cousini, two new species of neotropical planorbid mollusks. Revista Brasileira de Biologia, 26, $115-126$.

PARAENSE, W.L. 1972. Fauna planorbídica do Brasil. In: Introdução à Geografia Medica do Brasil. (G.S. Lacaz, R.G. Baruzzi, W. Siqueira, eds) Edgard Blucher, São Paulo.

PARAENSE, W.L. 1975. Estado atual da sistemática dos planorbídeos brasileiros. Arquivos do Museu Nacional, 55: 105-128.

PARAENSE, W.L. 1976. A natural population of Helisoma duryi in Brazil. Malacologia, 15: 360-376.

PARAENSE, W.L. 1988. Biomphalaria kuhniana (Clessin, 1883), planorbid mollusc from South America. Memórias do Instituto Oswaldo Cruz, 83: 1-12.

PARAENSE, W.L. 1996. Neotropical planorbid snails with apertural lamellae. I. Biomphalaria helophila (Orbigny, 1835). Memórias do Instituto Oswaldo Cruz, 92: 177-186.

PARAENSE, W.L. 2003. A bird's eye survey of Central American planorbid molluscs. Memórias do Instituto Oswaldo Cruz, 98: 51-67.

PARAENSE, W.L. 2004. Planorbidae, Lymnaeidae and Physidae of Ecuador (Mollusca: Basommatophora). Memórias do Instituto Oswaldo Cruz, 99: 357-362.

PARAENSE, W.L \& CORREA, L.R. 1973. Susceptibility of Biomphalaria peregrina from Brazil and Ecuador to two strains of Schistosoma mansoni. Revista do Instituto de Medicina Tropical de São Paulo, 15: 127-130.

PARAENSE, W.L \& CORREA, L.R. 1989. A potential vector of Schistosoma mansoni in Uruguay. Memórias do Instituto Oswaldo Cruz, 84: $281-288$.

PARAENSE, W.L., IBAÑEZ, N. \& MIRANDA, H. 1964. Australorbis tenagophilus in Peru, and its susceptibility to Schistosoma mansoni. American Fournal of Tropical Medicine and Hygiene, 13: 534-540.

PARAENSE, W.L., POINTIER, J.P., DELAY, B., PERNOT, A.F., INCANI, R.N., BALZAN, G. \& CHROSGIECHOWSKI, P. 1992. 
Biomphalaria prona (Gastropoda: Planorbidae): a morphological and biochemical study. Memórias do Instituto Oswaldo Cruz, 87: 171-179.

ROZAS, J. \& ROZAS, R. 1999. DnaSP version 3.5: an integrated program for molecular populations genetics and molecular evolution analysis. Bioinformatics, 15: 174-175.

SPATZ, L., VIDIGAL, T.H.D.A., CALDEIRA, R.L., DIAS NETO, E., CAPPA, S.M.G. \& CARVALHO, O.S. 1999. Study of Biomphalaria tenagophila, B. t. guaibensis and $B$. occidentalis by polymerase chain reaction amplification and restriction enzyme digestion of the ribosomal RNA gene intergenic spacer. Fournal of Molluscan Studies, 65: 143-149.

SWOFFORD, D.L. 2002. PAUP*. Phylogenetic analysis using parsimony (* and other methods). Version 4. Sinauer Associates, Sunderland, Massachusetts.

THOMPSON, J.D., HIGGINS, D.G. \& GIBSON, T.J. 1994. CLUSTAL W: improving the sensitivity of progressive multiple sequence alignment through sequence weighting, positions-specific gap penalties and weight matrix choice. Nucleic Acid Research, 22: 4673-4680.

VELÁSQUEZ, L.E., CALDEIRA, R.L., ESTRADA, V.E. \& CARVALHO, O.S. 2002. Morphological and polymerase chain reaction-restriction fragment length polymorphis characterization of Biomphalaria kuhniana and Biomphalaria amazonica from Colombia. Memórias do Instituto Oswaldo Cruz, 97: 997-1004.

VIDIGAL, T.H.D.A., CALDEIRA, R.L., SIMPSON, A.J.G. \& CARVALHO, O.S. 2000. Further studies on the molecular systematics of Biomphalaria snails from Brazil. Memórias do Instituto Oswaldo Cruz, 95: 57-66.

VIDIGAL, T.H.D.A., CALDEIRA, R.L., SIMPSON, A.J.G. \& CARVALHO, O.S. 2000a. Identification of Biomphalaria havanensis and Biomphalaria obstructa populations from Cuba using polymerase chain reaction and restriction fragment length polymorphism of the ribosomal RNA intergenic ipacer. Memórias do Instituto Oswaldo Cruz, 96: $661-665$.

VIDIGAL, T.H.D.A., KISSINGER, J.C., CALDEIRA, R.L., PIRES, E.C.R., MONTEIRO, E., SIMPSON, A.J.G. \& CARVALHO, O.S. 2000b. Phylogenetic relationships among Brazilian Biomphalaria species (Mollusca: Planorbidae) based upon analysis of ribosomal ITS2 sequences. Parasitology, 121: 611-620.

VIDIGAL, T.H.D.A., DIAS NETO, E., CARVALHO, O.S. \& SIMPSON, A.J.G. 1994. Biomphalaria glabrata: extensive genetic variation in Brazilian isolates by random amplified polymorphic DNA analysis. Experimental Parasitology, 79: 187-194.

VIDIGAL, T.H.D.A., SPATZ, L., NUNES, D.N., SIMPSON, A.J.G., CARVALHO, O.S. \& DIAS NETO, E. 1998. Biomphalaria spp: identification of the intermediate snail hosts of Schistosoma mansoni by polymerase chain reaction simplification and restriction enzyme digestion of the ribosomal RNA gene intergenic spacer. Experimental Parasitology, 89: 180-187.

VIDIGAL, T.H.D.A., SPATZ, L., KISSINGER, J.C., REDONDO, R.A.F., PIRES, E.C.R., SIMPSON, A.J.G. \& CARVALHO, O.S. 2004. Analysis of the first and second internal transcribed spacer sequences of the ribosomal DNA in Biomphalaria tenagophila complex (Mollusca: Planorbidae). Memórias do Instituto Oswaldo Cruz, 99: 153-158.

WORLD HEALTH ORGANIZATION (WHO). 1993. The control of schistosomiasis. Second report of the WHO expert committee. Technical Report Series Geneva, Switzerland, 830: 86.

WORLD HEALTH ORGANIZATION (WHO). 1998. Rapport de la Consultation informelle de L'OMS sur la lutte contre la schistosomiase. OMS, Genève (WHO/CDS/SIP/99). 